
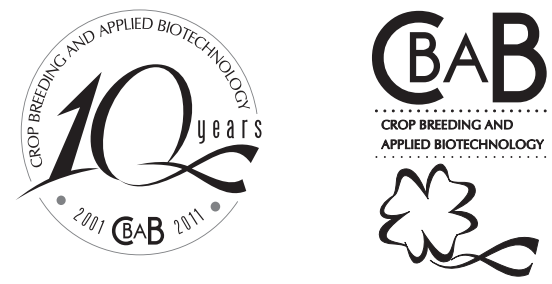

\title{
RB965902 and RB965917 - Early/medium maturing sugarcane varieties
}

\author{
Monalisa Sampaio Carneiro ${ }^{1 *}$, João Ricardo Bachega Feijó Rosa ${ }^{1}$, Fernanda Zatti Barreto ${ }^{1}$, Thiago Willian Almeida Balsalobre ${ }^{1}$, \\ Roberto Giacomini Chapola ${ }^{1}$, Marcos Antonio Sanches Vieira ${ }^{1}$, Antonio Ismael Bassinello ${ }^{1}$ and Hermann Paulo Hoffmann ${ }^{1}$
}

Received 21 September 2010

Accepted 24 February 2011

ABSTRACT - The varieties RB965902 and RB965917 were developed for harvesting at the beginning to the middle of the sucrose extraction period (early/medium maturity) and released for the South-Central region of Brazil. In specific environments, the tons of Pol per area (sucrose yield) of these varieties is higher than of the commercial standard RB855453 and they are resistant to the main diseases of the crop.

Key words: Saccharum, Ridesa, sugarcane breeding program.

\section{INTRODUCTION}

The complex Saccharum spp. (known as sugarcane) is believed to be originated from complex natural hybridization events (called nobilization) between Saccharum officinarum, S. barberi, S. sinense, and related wild species S. spontaneum (Sreenivasan et al. 1987). Sugarcane is predominantly allogamous, highly heterozygous, and vegetatively propagated. There are currently four sugarcane breeding programs in Brazil: the Agronomical Institute of Campinas, whose varieties are labeled with the abbreviation IAC; the Center of Sugarcane Technology, with the identification code CTC, the Inter University Network for the Development of Sugar and Alcohol - RIDESA, with the varietal acronym RB varieties (Republic of Brazil), and CanaVialis/Monsanto with the initials CV.

RIDESA is a partnership of 10 Federal Universities with the purpose to develop improved sugarcane varieties.
RIDESA was created after the extinction of the earlier governmental sugarcane breeding program Planalsucar. The creation of RIDESA was an important step towards coordinated nationwide actions for a technological support of one of the most important segments of the Brazilian economy. The consortium consists of 10 universities (UFSCar, UFRPE, UFAL, UFRRJ, UFV, UFG, UFPR, UFS, UFPI, and UFMT) that sustain and share the sugarcane flowering and crossing station denominated Serra do Ouro, in Murici/AL, and experimental units forming a national test network for sugarcane breeding. In over 20 years, RIDESA has released $78 \mathrm{RB}$ sugarcane varieties, which are currently planted on $58 \%$ of the area cultivated with sugarcane in Brazil (Daros et al. 2010).

The Federal University of São Carlos (UFSCar) is responsible for developing $\mathrm{RB}$ varieties for the SouthCentral region of Brazil, in the states of Sao Paulo and Mato Grosso do Sul. This region has the largest sugarcane area and highest cane production in Brazil. The varieties

\footnotetext{
${ }^{1}$ Universidade Federal de São Carlos, Centro de Ciências Agrárias, PMGCA/FAI-UFSCar, 13.600-970, Araras, SP, Brazil. *Email: monalisa@cca.ufscar.br
} 
RB965902 and RB965917 were developed and released in 2010 by the UFSCar breeding program.

\section{BREEDING PROGRAM}

The varieties RB965902 and RB965917 are full-sibs and were obtained from a reciprocal, biparental cross between the varieties RB855536 x RB855453 (Figure 1). The crosses were carried out at the sugarcane flowering and crossing station Serra do Ouro, in Murici/AL $\left(09^{\circ} 18^{\prime}\right.$ $\mathrm{S}, 35^{\circ} 56^{\prime} \mathrm{W}, 450 \mathrm{~m}$ asl). The obtained seeds were germinated and then planted in the field, establishing the first phase of selection (T1). At this stage, clones from a single clump were selected by mass selection in the first ratoon cane cycle (Breaux et al. 1963), based on criteria of important industrial morphological characteristics such as brix and stalk number (Hogarth 1987, Berding et al. 2004), flowering, pithiness and resistance to the main diseases (Matsuoka et al. 1999). The clones were compared to standard commercial varieties with early and medium/late maturity.

Based on these criteria, clones were selected which, together with early-maturing standard commercial varieties, constituted the second phase of selection (T2). In this step, the clones were established in Araras $\left(22^{\circ} 211 \mathrm{~S}, 47^{\circ}\right.$ $23^{\prime} \mathrm{W}$; $620 \mathrm{~m}$ asl) and Valparaiso (21 ${ }^{\circ} 13^{\prime} \mathrm{S}, 50^{\circ} 52^{\prime} \mathrm{W}$; $450 \mathrm{~m}$ asl), state of São Paulo, in an augmented block design (Federer 1956). The plots consisted of a 7-m row with one replication. The clones were evaluated in plant cane and first ratoon cane, based on the same criteria as in stage T1 together with the parameters cane weight per plot and kilo brix per plot - KBP (Kang et al. 1983).

The selected T2 clones were advanced to the third stage of selection (T3), also arranged in augmented blocks (Federer 1956). The plots consisted of two 5-m rows spaced $1.40 \mathrm{~m}$ apart, with two replications. The T3 genotypes were tested at 10 different locations in the Central South. The selection was based on the average performance of plant cane and first ratoon cane in different test environments. The selection criteria were similar to stage T2, plus Pol in juice \% (sucrose content) and kilo pol per plot - KPP as additional parameters (Matsuoka et al. 1999).

After phase T3, the selected clones were advanced to the final experimental stage of selection, called FE. At this stage, the promising genotypes were assessed at 25 locations across the South-Central region, considering the data of four cycles (plant cane, first cane ratoon, $2^{\text {nd }}$ and $3^{\text {rd }}$ ratoons). The field trials were established randomized complete blocks with three replications, with earlymaturing, standard commercial varieties distributed within blocks as controls. The parameters were tons of cane per hectare - $\mathrm{TCH}$ (cane yield), Pol in cane in \% - PC (sucrose content), tons of Pol per hectare - TPH (sucrose yield) and fiber content in \%. The coefficient of environmental variation, the effects of genotype-environment interaction and the clone adaptability and stability were estimated by individual (of each location) and combined analysis of variance (of all locations) (Steel and Torrie 1960). The maturation curve of the FE promising test clones was evaluated to identify the best harvest time in terms of the level of Pol in cane in \% (sucrose content). The bestperforming genotypes were multiplied and evaluated in the partnership units to observe the performance under production conditions (Barbosa et al. 2001, Barbosa et al. 2004). In 2010, the varieties RB965902 and RB965917 were officially released by UFSCar.

\section{PERFORMANCE}

\section{RB965902}

The growth habit of the variety is slightly decumbent and the leaves (trash) can be removed relatively easily; it has a good canopy cover and excellent ratoon regrowth from green and burnt cane, sparing an early replanting of the cane fields. The tillering capacity inboth plant and first ratoon caneis particularly high.

The fiber content is medium, maturation early to medium, flowering absent and pithiness low. In the Central South, RB965902 is indicated for harvesting between May and July. The constant PC content of this variety allows harvesting until mid-August and processing after RB855453.

The TCH of RB965902 in unfavorable environments is higher than of RB855453 and yields are more stable under improved soil and climate conditions (Figure 2). For production in the Central South, cultivation in moderate and favorable environments is recommended (Prado 2008).

With high agricultural productivity ( $\mathrm{TCH}$ above $120 \mathrm{t} / \mathrm{ha}$ ) and PC of about $13.5 \%$, the TPH of RB965902 is similar to the early/medium-maturing commercial standard varieties (Figure 3).

\section{RB965917}

The growth habit of the variety is upright, stalks are tall and little lodging occurs up to an age of 12 months. It has a fast canopy cover, excellent regrowth and high tillering in plant and ratoon cane. It stands out with high agricultural productivity in favorable environments and excellent performance of mechanical harvesting. 
MS Carneiro et al.

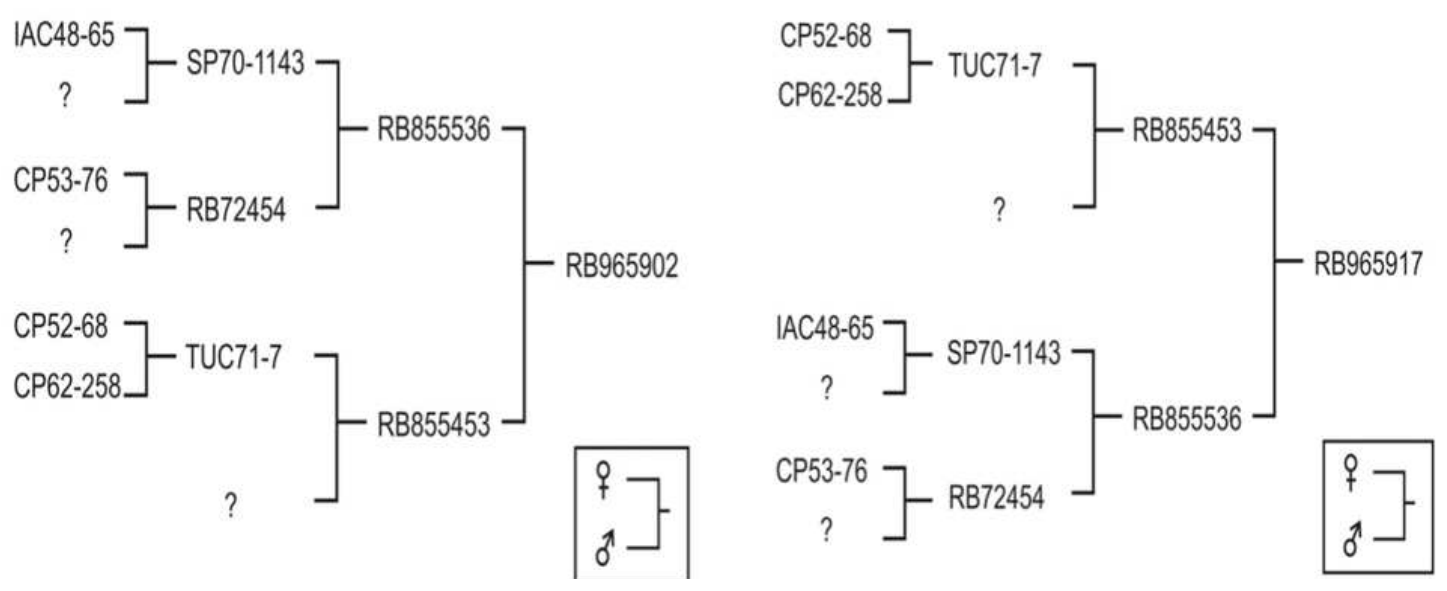

Figure 1. Pedigree of the sugarcane varieties RB965902 and RB965917.
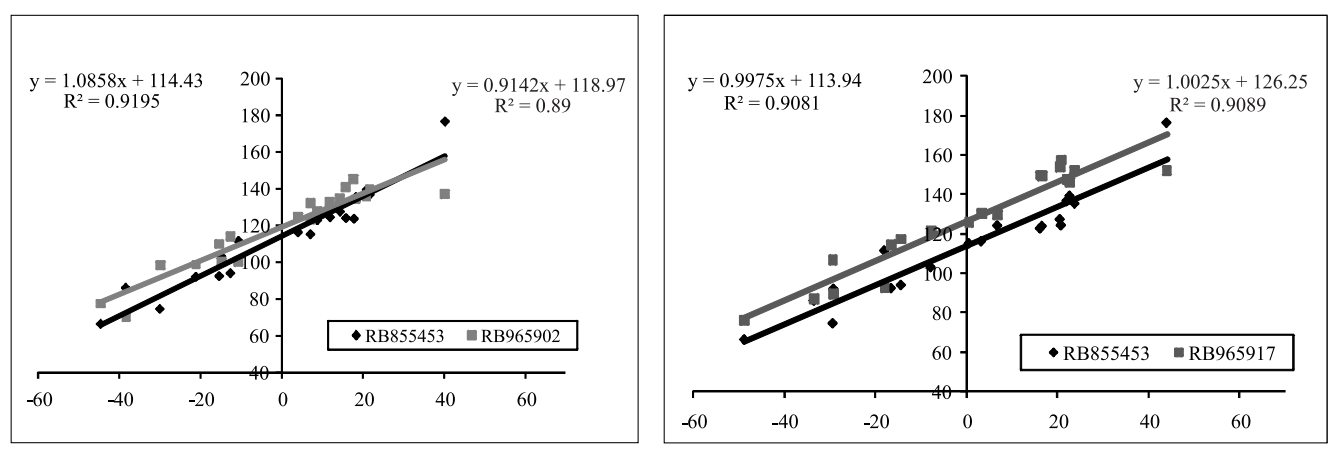

Figure 2. Adaptability and stability of the varieties RB965902 and RB965917 compared to the commercial standard RB855453. The mean data of tons of cane per hectare (TCH) in 18 field trials in a first ratoon cane cycle were adjusted based on regression analysis (Eberhart and Russell 1966).

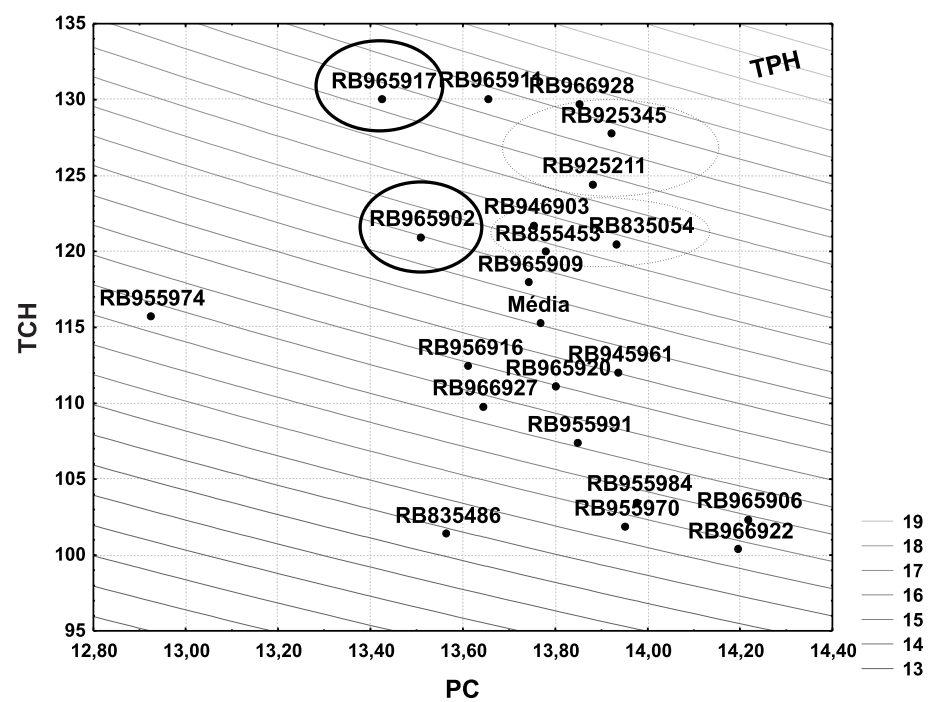

Figure 3. Isoquants of mean data of $\mathrm{Pol}$ in cane in $\%(\mathrm{PC})$ and tons of cane per hectare (TCH) in 18 field trials and 3 cycles in different production environments. The diagram shows the varieties RB965902 and RB965917 (drawn-out circles) for comparison with the standard commercial varieties (dotted circles) and clones. 
The fiber content is medium, maturation early to medium, flowering absent and pithiness low. In the Central South, RB965917 is indicated for harvesting between June and August. The constant PC content of this variety allows harvesting until mid-September and can be processed after RB855453.

The variety RB965917 has higher TCH in both favorable and unfavorable environments than RB855453, with lower yield stability (Figure 2). For commercial production, RB965917 is adequate in favorable environments (Prado 2008), under similar production conditions to those of RB855453.

The high agricultural productivity $(\mathrm{TCH}$ above $130 \mathrm{t} \mathrm{ha}^{-1}$ ) and the PC concentration of about $13.4 \%$ of RB965917 indicate an equivalent or higher TPH than of the early/medium-maturing, commercial standard varieties (Figure 3).

\section{OTHERFEATURES}

\section{Disease reaction}

The varieties RB965902 and RB965917 in stage T3 were subjected along with other genotypes to natural disease infection and artificial inoculation tests. These tests were conducted to verify the reaction of varieties and clones against the major diseases of sugarcane in the South-Central region of Brazil.

The test was conducted in a region with high inoculum pressure, favorable for the natural infection of various diseases, such as Brown Rust (Puccinia melanocephala), Smut disease (Ustilago scitaminea), Mosaic (Sugarcane Mosaic Virus - SCM) and Leaf Scald (Xanthomonas albilineans). The varieties RB965902 and RB965917, as the others, were evaluated based on the number of infected tillers (infection \%) over two consecutive years, in the plant and first ratoon cane cycles.

In the artificial test in a greenhouse, RB965902 and RB965917 plants were inoculated with spores of the causal fungus of Smut disease and the causal agent of Mosaic virus, according to methods described by Matsuoka (1979). The varieties were evaluated based on a grading scale for each disease, where the number of infected tillers is counted (\% infection) and the genotypes are classified in resistant, intermediate and susceptible.
Based on the tests of natural infection and artificial inoculation, the varieties RB965902 and RB965917 were considered resistant to the sugarcane diseases brown rust, Smut disease, and Leaf Scald. The resistance of RB965917 was considered intermediate to Red Stripe, another important sugarcane disease.

\section{CHARACTERIZATIONBY MICROSATELLITE GENOTYPING}

The molecular fingerprints of RB965917 and RB965902 were generated with a panel of 17 microsatellite markers derived from sugarcane expressed sequence tags (EST-SSRs), developed by Oliveira et al. (2007), and were compared with those of five other cultivars (RB72454, RB835486, SP80-3280, SP81-3250 and RB966928). The 17 microsatellite loci amplified a total of 136 fragments in the seven cultivars, with sizes ranging from 192 to 291 base pairs (bp).

Due to the polyploid nature of sugarcane, most of the selected EST-SSRs produced more than two alleles per genotype, on average eight alleles, ranging from 4 (SCB 64) to 12 (SCB 125) alleles. The Polymorphic Information Content (PIC) had a mean value of 0.80 , ranging from 0.70 (SCB 2007) to 0.88 (SCB 40). The information of discriminatory power (DP) ranged from 1 (SCB 125, SCB and 40) and 0.91 (SCB 2007), with an average value of 0.98 .

Absence and presence of fragments were coded as a binary $(0,1)$ matrix, which was used to generate an unweighted pair group method using arithmetic averages (UPGMA) (Figure 4) from similarity indices among the seven cultivars (Dice 1945). Results indicate that the varieties RB965902 and RB965917 were genetically closer to each other than to the others.

\section{BASIC SEED MAINTENANCEAND DISTRIBUTION}

The varieties RB965902 and RB965917 are being produced by the UFSCar Breeding Program and are available for research purposes at the Agricultural Science Center, Araras - SP, where they will be maintained for at least five years from the date of publication. 
MS Carneiro et al.

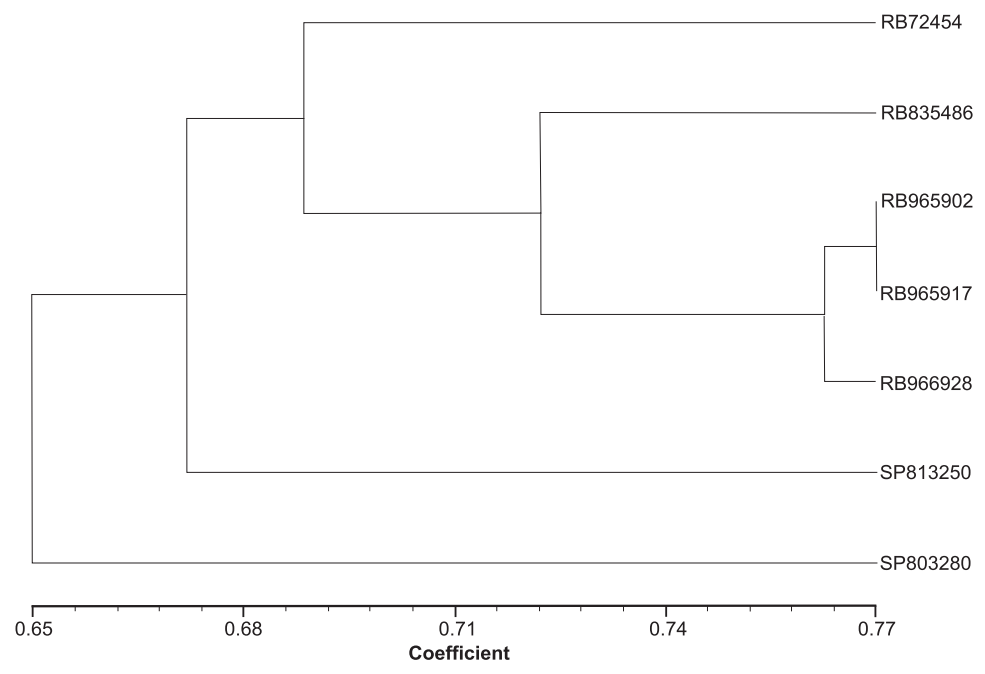

Figure 4. Dendrogram based on UPGMA representing the similarity of Dice among 7 sugarcane varieties analyzed with 17 microsatellite loci.

\section{RB965902 e RB965917 - Variedades de cana-de-açúcar com maturação precoce/média}

RESUMO - As variedades RB965902 e RB965917 foram desenvolvidas e liberadas para colheita no início até o meio da safra (maturação precoce/média) na região Centro-Sul do Brasil. Em ambientes específicos, essas variedades superam o padrão comercial RB855453 em produção de pol por área. Apresentam resistência às principais doenças da cana-de-açúcar.

Palavras-chave: Saccharum, Ridesa, programa de melhoramenbto de cana.

\section{REFERENCES}

Barbosa MHP, Silveira LCI, Oliveira MW, Souza VFM and Ribeiro SNN (2001) RB867515 Sugarcane cultivar. Crop Breeding and Applied Biotechnology 1: 437-438.

Barbosa MHP, Silveira LCI, Souza VFM and Ribeiro SNN (2004) RB928064 - Sugarcane cultivar. Crop Breeding and Applied Biotechnology 4: 356-359.

Berding N, Hogarth M and Cox M (2004) Plant improvement of sugarcane. In James GL (ed.) Sugarcane. Blackwell Science, Oxford, p. 1-19.

Breaux RD, Hebert LP and Fanguy HP (1963) Defects for which sugarcane seedlings are eliminated at the U.S. Sugar Cane Field Station, Houma, Louisiana. In Proceedings of Congress of International Society of Sugarcane Technologists. Elsevier, Amsterdam, p. 421-424.

Daros E, Zambon JLC, Oliveira RA and Bespalhok Filho JC (eds.) (2010) Liberação nacional de novas variedades "RB" de cana-de-açúcar. AJIR, Curitiba, 64p.
Dice LR (1945) Measures of the amount of ecological association between species. Ecology 26: 297-307.

Eberhart SA and Russell WA (1966) Stability parameters for comparing varieties. Crop Science 6: 36-40.

Federer WT (1956) Augmented (or Hoonuiaku) designs. Hawaiian Planters' Record 55: 191-208.

Hogarth DM (1987) Genetics of sugarcane. In Heinz DJ (ed.) Sugarcane improvement through breeding. Elsevier, Amsterdam, p. 255-271.

Kang MS, Miller JD and Tai PYP (1983) Genetic and phenotypic path analysis and heritability in sugarcane. Crop Science 23: 643-647.

Matsuoka S (1979) Método para pré-testagem de clones de canade-açúcar ao carvão e ao mosaico conjuntamente. In I Congresso nacional da sociedade dos técnicos açucareiros e alcooleiros do Brasil. STAB, Maceió, p. 231-233.

Crop Breeding and Applied Biotechnology 11: 280-285, 2011 
RB965902 and RB965917 - Early/medium maturing sugarcane varieties

Matsuoka S, Garcia AAF and Arizono H (1999) Melhoramento da cana-de-açúcar. In Borém A (ed.) Melhoramento de espécies cultivadas. Editora UFV, Viçosa, p. 205-252.

Oliveira KM, Pinto LR, Marconi TG, Mollinari M, Ulian EC, Chabregas SM, Falco MC, Burnquist W, Garcia AAF and Souza AP (2007) Characterization of new polymorphic functional markers for sugarcane. Genome 52: 191-209.
Prado H (2008) Pedologia fácil: aplicações na agricultura. Hélio do Prado, Piracicaba, 45p.

Sreenivasan TV, Ahloowalia BS and Heinz DJ (1987) Cytogenetics. In: Heinz DJ (ed.) Sugarcane improvement through breeding. Elsevier, Amsterdam, p. 211-253.

Steel RGD and Torrie JH (1960) Principles and procedures of statistics. McGraw-Hill, New York, 481p. 